\title{
Coordinated Seasonal Regulation of Metabolic and Reproductive Hypothalamic Peptides in the Desert Jerboa
}

\author{
Rajae Talbi, ${ }^{1,2}$ Paul Klosen, ${ }^{1}$ Marie-Pierre Laran-Chich, ${ }^{1}$ Seloua El Ouezzani, ${ }^{2}$ and Valérie Simonneaux ${ }^{1}$ * \\ ${ }^{1}$ Institute of Cellular and Integrative Neurosciences, Department of Neurobiology of Rhythms, CNRS UPR 3212, University of Stras- \\ bourg, Strasbourg, France \\ ${ }^{2}$ Laboratory of Neuroendocrinology and Nutritional and Climatic Environment, Faculty of Sciences, University of Sidi Mohammed \\ Ben Abdellah, BP 1796-ATLAS, FES, Morocco
}

\begin{abstract}
Jerboa (Jaculus orientalis) is a semi-desert rodent displaying strong seasonal variations in biological functions in order to survive harsh conditions. When environmental conditions become unfavorable in early autumn, it shuts down its reproductive axis, increases its body weight, and finally hibernates. In spring, the jerboa displays opposite regulations, with a reactivation of reproduction and reduction in body weight. This study investigated how genes coding for different hypothalamic peptides involved in the central control of reproduction (Rfrp and Kiss1) and energy homeostasis (Pomc, Npy, and Somatostatin) are regulated according to seasons in male jerboas captured in the wild in spring or autumn. Remarkably, a coordinated increase
\end{abstract}

in the mRNA level of Rfrp in the dorso/ventromedial hypothalamus and Kiss1, Pomc, and Somatostatin in the arcuate nucleus was observed in jerboas captured in spring as compared to autumn animals. Only Npy gene expression in the arcuate nucleus displayed no significant variations between the two seasons. These variations appear in line with the jerboa's seasonal physiology, since the spring increase in Rfrp and Kiss 1 expression might be related to sexual reactivation, while the spring increase in genes encoding anorexigenic peptides, POMC, and somatostatin may account for the reduced body weight reported at this time of the year. J. Comp. Neurol. 524:3717-3728, 2016.

(c) 2016 Wiley Periodicals, Inc.

INDEXING TERMS: RFRP-3; kisspeptin; POMC; somatostatin; NPY; jerboa

Species in their natural environment have to adapt their biological functions to seasonal changes in food resources. In mammals, the nocturnal production of the pineal hormone melatonin is critical for seasonal cue integration and adaptation (Reiter, 1993). Melatonin has been demonstrated to synchronize physiological functions with seasonal changes in order to guarantee species survival and maintain adequate body homeostasis. Reproduction and metabolic activity are crucial melatonin-regulated physiological functions (Barrett and Bolborea, 2012; Dardente, 2012; Hazlerigg and Simonneaux, 2014). Furthermore, considering that reproduction is an energetically demanding process, it is critical that both seasonal reproductive and metabolic activities are synchronized. It is therefore expected that the neuronal mechanisms controlling these functions display seasonal correlations and interact with each other. In fact, in the last decade evidence has suggested that

(c) 2016 Wiley Periodicals, Inc. "reproductive" neuropeptides are also involved in the control of feeding behavior, while "metabolic" neuropeptides can communicate with the reproductive axis (Schneider, 2004; Fernandez-Fernandez et al., 2006; Hill et al., 2008; Garcia-Garcia, 2012; Evans and Anderson, 2012).

Key hypothalamic peptides are known to regulate reproductive activity and metabolism in mammalian species. Kisspeptin (Kp) and RFRP-3 (also named GnIH, for gonadotropin inhibitory hormone) are two RF-amide peptides recently shown to be regulators of

\footnotetext{
Grant sponsor: ANR Repramide; Grant number: 13-BSV1-0001.

*CORRESPONDENCE TO: Valérie Simonneaux, INCI CNRS 321, 5 rue Blaise Pascal, 67084 Strasbourg, France. E-mail: simonneaux@inci-cnrs. unistra.fr

Received August 28, 2015; Revised December 3, 2016; Accepted April 20, 2016.

DOI $10.1002 /$ cne. 24026

Published online May 23, 2016 in Wiley Online Library (wileyonlinelibrary.com)
} 
reproduction in a wide range of mammals (Kriegsfeld et al., 2010; Pinilla et al., 2012). Kp is expressed in neurons located in two hypothalamic regions, the anteroventral periventricular nucleus (AVPV) and the arcuate nucleus (ARC) (Gottsch et al., 2004; Smith et al., 2005; Mikkelsen and Simonneaux, 2009). Kp is a potent activator of $\mathrm{GnRH}$ neurons and gonadotropin release in all mammalian species, including humans (Gottsch et al., 2004; Thompson et al., 2004; Dhillo et al., 2005; Messager et al., 2005). RFRP-3 is expressed in neurons exclusively located in the dorso $(\mathrm{DMH})$ and ventro $(\mathrm{VMH})-$ medial hypothalamus (Kriegsfeld et al., 2006; Revel et al., 2008). Its role in the regulation of reproductive activity appears to depend on species and sex, exhibiting either stimulatory (Ancel et al., 2012; Ubuka et al., 2012) or inhibitory effects (Kriegsfeld et al., 2006; Clarke et al., 2008; Johnson et al., 2007; Pineda et al., 2010). On the other hand, pro-opiomelanocortin (POMC), neuropeptide Y (NPY), and somatostatin are hypothalamic peptides well known to regulate feeding behavior. NPY, synthesized in ARC neurons, is one of the most powerful orexigenic neuropeptides regulating food intake and body weight (Bai et al., 1985; Morley, 1987; Leibowitz, 1991). POMC is a precursor polypeptide synthesized in the ARC, the nucleus tractus solitarius of the brainstem, and the pituitary. POMC produces several biologically active peptides known to play a pivotal role in the regulation of energy balance, among which $\beta$-endorphin, ACTH, and $\alpha$-MSH display strong effects on food intake (Fan et al., 1997; Murphy et al., 1998; Schulz et al., 2010). Somatostatin is a multifunctional neuropeptide produced by the periventricular nucleus of the hypothalamus, the ARC, and other neuronal populations (Guillemin and Gerich, 1976). It binds to receptors located in various brain nuclei involved in feeding regulation, notably the ARC, and it regulates food intake in various mammalian species (Lotter et al., 1981; Danguir, 1988; Fehlmann et al., 2000; Stengel et al., 2010, 2015). Interestingly, independent studies have reported that Kp (Revel et al., 2006a; Smith et al., 2008), RFRP3 (Revel et al., 2008; Smith et al., 2008), NPY (Lakhdar-Ghazal et al., 1995; Reuss and Olcese, 1995; Skinner and Herbison, 1997), $\beta$-endorphin (Roberts et al., 1985; Ebling and Lincoln, 1987), and somatostatin (Webb et al., 1985; Herwig et al., 2012; Klosen et al., 2013; Dumbell et al., 2015) display significant variations in the brain of different mammalian species placed in artificial long or short photoperiods.

In this study we chose the jerboa (Jaculus orientalis) as a wild animal model for analyzing the neuronal mechanisms involved in the anticipatory adaptation to harsh environmental cues. The jerboa is a semi-desert rodent whose reproductive and metabolic activities are well adapted to marked environmental changes. This species is sexually active in spring and early summer (Ghobrial and Hodieb, 1973; El Ouezzani et al., 2000; El Qandil et al., 2004) and hibernates at low ambient temperatures (Andjus et al., 1974; El Ouezzani et al., 2011). It displays seasonal variations in the nocturnal production of melatonin (Lakhdar-Ghazal et al., 1992) and melatonin inhibits testicular activity in male jerboas (El Qandil et al., 2004). Additionally, previous studies reported that jerboas display seasonal variations in body weight and food intake (El Ouezzani et al., 2011; Talbi et al., unpublished data). The seasonal changes in reproductive activity are accompanied by variations in the content of hypothalamic peptides involved in the central control of reproductive activity. Thus, gonadotropin releasing hormone $(\mathrm{GnRH})$ displays seasonal variations and melatonin appears to regulate $\mathrm{GnRH}$ immunoreactivity in both neurons of the preoptic area and fibers in the median eminence (El Ouezzani et al., 2000; El Qandil et al., 2004). Kp and RFRP-3 immunoreactivity is higher in the hypothalamus of sexually active male jerboas captured in spring as compared to sexually inactive animals of autumn (Janati et al., 2013). Alternatively, $\beta$-endorphin displays lower levels in the rostral ARC of jerboas sacrificed during spring-summer as compared to those sacrificed in autumn (El Ouezzani et al., 2005).

In the present study, we investigated seasonal variations in the expression of genes coding for Kp, RFRP-3, POMC, somatostatin, and NPY by comparing their mRNA levels in the hypothalamus of male jerboas captured from the wild in spring or autumn, and correlated these values to the reproductive and metabolic status of the animals.

\section{MATERIALS AND METHODS \\ Animals}

Sexually mature male jerboas weighing $139.4 \pm 5.4$ $\mathrm{g}(n=8)$ were captured in the field of the middle Atlas Mountains of Morocco (sub-desert high plateaus of Ifkerne-Boulmane; altitude $1,565 \mathrm{~m}$, longitude $-4,73$, latitude 33,36) in spring (May, $n=4$ ) when they are sexually active and autumn (November, $n=4$ ) when they are sexually inactive. Males rather than females were chosen in this study because sexual maturation and status are difficult to assess in female jerboa captured in the wild and this could interfere with the seasonal parameters under investigation. The animals were transported to the University of Fes, where they were maintained together in a single cage $(90 \times 60 \times 50$ $\mathrm{cm}$ ) in a room with open windows and kept under 
natural conditions of temperature and photoperiod. Food (sunflower and barley seeds and vegetables) was provided ad-libitum. Animal experimentation was performed in accordance with the international guidelines for the Care and Use of Mammals in Neurosciences and Behavioral Research (2003).

\section{Brain tissue preparation}

After 1 week of adaptation, animals were anesthetized with an intraperitoneal injection of ethyl urethane (1 ml/100g, Acros Organics, Morris Plains, NJ) between 10-12 AM. The blood was taken by cardiac puncture, centrifuged at $4000 \mathrm{rpm}$ for 10 minutes and the plasma was extracted and stored at $-20^{\circ} \mathrm{C}$ for testosterone assay. Animals were transcardially perfused with $50 \mathrm{ml}$ of isotonic saline solution ( $\mathrm{Nacl} 9 \%$ ) followed by 250 $\mathrm{ml}$ of $4 \%$ formaldehyde (Sigma-Aldrich, St. Louis, MO) in $0.1 \mathrm{M}$ phosphate buffer at $\mathrm{pH} 7.6$ (PB). Perfused testes were dissected out and weighed. The animals' head was first kept in $4 \%$ paraformaldehyde for 1 hour, then the brains were removed, postfixed for 24 hours in the same fixative solution, dehydrated in ethanol baths of increasing concentrations, and then included first in polyethylene glycol 1000 (PEG, Acros Organics) followed by a mixture of PEG 1000/PEG 1500 according to Klosen et al. (1993). Twelve $\mu \mathrm{m}$ coronal brain sections were cut from the suprachiasmatic nucleus to the mammillary bodies using a microtome (Leica 2055 autocut, Rueil-Malmaison, France), mounted on Superfrost ultraplus slides (Menzel-Gläser, Braunschweig, Germany) under RNAse free conditions, and stored at $80^{\circ} \mathrm{C}$ until use for in situ hybridization.

\section{Nonradioactive in situ hybridization Riboprobe preparation and validation}

Since none of the available rodent Rfrp riboprobes hybridized to the jerboa Rfrp mRNA, we cloned the jerboa's Rfrp gene. Total RNA was extracted from two fresh jerboa hypothalami (GeneJet RNA purification kit; Thermo Fisher Scientific, Waltham, MA) and reverse transcribed into cDNA (Superscript III, Thermo Fisher Scientific). Touchdown polymerase chain reaction (PCR) was then conducted using forward (CATCTTGTTGACTTTAGCCACTTC) and reverse (AGAAGATGGCATGAAGCTGT) primers designed according to the Jaculus jaculus gene sequence (NC_005314.1). The 614 bp cDNA fragment obtained was cloned into the pST Blue1 vector (Perfectly Blunt Cloning Kit, Novagen, Merck, Darmstadt, Germany). Sequencing of the cDNA fragment confirmed that it contained the jerboa's Rfrp sequence (LGC Genomics, Germany). Sense and antisense jerboa Rfrp, Siberian hamster Kiss1 (380 bp, 99\% identical to 187-566 of Mus musculus, Genbank
AB_666166.1), rat Npy (87-522 of Genbank NM_012614.2), rat Pomc (157-731 of Genbank NM_139326) and rat Somatostatin (135-465 of Genbank NM_012659) riboprobes were transcribed from linearized plasmids in the presence of digoxigeninlabeled nucleotides according to manufacturer protocol (Dig RNA Labelling Kit, Roche Diagnostics, Mannheim, Germany). The length of all probes was confirmed by formaldehyde-3-[N-morpholino]propanesulfonic acid agarose gel electrophoresis and northern blotting. The specificity of all riboprobes was assessed by the absence of signal with sense probes, resistance of signal to posthybridization RNAse treatment, posthybridization under high stringency conditions (SSC $0.1 \times$, $72^{\circ} \mathrm{C}$ ), and expected neuroanatomical localization (see Results).

\section{Hybridization}

Riboprobe hybridization was performed according to a protocol previously validated in our laboratory (Klosen et al., 2013). Brain sections including ARC (for Kiss1, Pomc, Npy, and Somatostatin) and DMH/VMH (for Rfrp) were postfixed for 10 minutes at room temperature in $4 \%$ formaldehyde, rinsed in phosphate buffered saline (PBS, $\mathrm{pH} 7.6)$, and then treated with $1 \mu \mathrm{g} / \mathrm{ml}$ proteinase $\mathrm{K}$ (Roche, Meylan, France) for 30 minutes at $37^{\circ} \mathrm{C}$. Proteinase $\mathrm{K}$ digestion was stopped with $2 \%$ phosphatebuffered formaldehyde. Sections were then acetylated twice for 10 minutes with $0.25 \%$ acetic anhydride in $100 \mathrm{mM}$ triethanolamine, rinsed twice in PBS containing $0.02 \%$ dimethyl-pyrocarbonate (DMPC), and preincubated in a solution containing $5 \times$ saline sodium citrate buffer (SSC), 0.05\% Tween-20, and 0.02\% DMPC. Hybridization was performed for 40 hours at $60^{\circ} \mathrm{C}$ with $200 \mathrm{ng} / \mathrm{ml}$ of antisense or sense probe in a solution containing $50 \%$ formamide, SSC $5 \times$, Denhardt's solution $5 \times, 1 \mathrm{mg} / \mathrm{ml}$ salmon sperm DNA, 0.1\% Tween-20, and $0.04 \%$ DMPC. Posthybridization steps included six rinses of high stringency each for 10 minutes in SSC $0.1 \times, 0.05 \%$ Tween- 20 at $72^{\circ} \mathrm{C}$ followed by two rinses in A-Dig buffer (Tris (hydroxymethyl) aminomethane 100 mM; NaCl 150 mM; MgCl2 2.5 mM; 0.05\% Tween-20; $\mathrm{pH}$ 7.5). Digoxigenin-labeled probes were detected with an alkaline phosphatase-labeled anti-digoxigenin antibody (1/5,000, Roche, Meylan, France). Alkaline phosphatase activity was detected with bromo-chloro-indolyl phosphate and nitroblue tetrazolium. The slides were incubated with the detection solution in the dark at room temperature. The signal level was checked periodically and the development of the alkaline phosphatase signal was stopped before a too strong signal developed in order to avoid saturation of the signal ( 8 to 10 hours for Rfrp, Pomc, Npy, and Somatostatin, and 
48 hours for Kiss 1). All sections and slides to be analyzed for one experiment were processed and developed together under identical conditions. Finally, the slides were mounted with an aqueous mounting medium (CC/MountTM, Sigma, St. Quentin Fallavier, France) and coverslipped with Eukitt (Kindler). For each peptide mRNA, we prepared serial sections throughout the ARC for Kiss1, Pomc, Npy, and Somatostatin and the DMH/VMH for Rfrp. For these serial sections, we selected 1 section every 12 sections with each series containing 12 sections, thus covering a total rostrocaudal extent of $1,728 \mu \mathrm{m}$ (12 sections of $12 \mu \mathrm{m}$ sections of a 1 in 12 series). All spring and autumn animal sections were treated together.

\section{Semi-quantification of hybridized peptide mRNA}

Both the number of labeled neurons and the intensity of labeling per neuron were measured in the jerboa's hypothalamus. Neuron counts were performed by two observers unaware of the animal groups. There was no significant difference between either observers; therefore, the data given is the one obtained by the first author. The number of Kiss 1, Pomc, Somatostatin, and Npy neurons was estimated by counting the labeled cells throughout the entire ARC. The rostral, middle, and caudal parts of the ARC correspond to sections localized between $-2,12$ and $-2,30 \mathrm{~mm} /$ bregma, $-2,8$ and $-3,14 \mathrm{~mm} /$ bregma, and $-3,6$ and $-3,8 \mathrm{~mm} /$ bregma, respectively. These levels are the corresponding levels of the rat brain as defined in the rat brain atlas of Paxinos and Watson (2005). The number of Rfrp neurons was also estimated by counting the number of labeled cells throughout the entire the DMH/ VMH area. All neurons were counted on both sides of the ventricle at the level of the ARC for Kiss1, Pomc, Somatostatin, and Npy, and of the DMH/VMH for Rfrp. For each peptide, the total number of neurons was calculated by first multiplying the total number of counted neurons by 12 ( 1 in 12 sections sampled per series). This gross number of counted neurons was then corrected using Abercrombie's correction factor for splitcell counting errors where $\mathrm{N}_{\text {corr }}=\mathrm{N} \times[\mathrm{t} / \mathrm{t}+\mathrm{d}]\left(\mathrm{N}_{\text {corr }}=\right.$ Total corrected number of neurons; $\mathrm{N}=$ counted number of neurons $\times 12$; $t=$ section thickness; and $d=$ mean neuron diameter) (Abercrombie, 1946). We used the mean diameter of the labeled neurons as an estimate of their rostrocaudal extent. The labeled neurons mostly appeared ovoid or round with no preferential orientation. The mean diameter of the neurons was estimated on 40 labeled cells for each animal and each peptide. The cell contour first was drawn on sizecalibrated images in Image $(\mathrm{NIH}$, Bethesda, MD). An ellipse was then fitted on the cell contour using the "Fit
Ellipse" command of ImageJ. Finally, the mean diameter of each cell was then calculated using the maximal and minimal diameters of the fitted ellipse. This mean diameter was then used to calculate Abercrombie's correction factor for each animal and each peptide. The mean diameter for Kiss1 neurons was: $d_{\text {autmun }}=11.94 \mu \mathrm{m}$ and $d_{\text {spring }}=13.59 \mu \mathrm{m}$; Npy neurons: $d_{\text {autmun }}=14.24$ $\mu \mathrm{m}$ and $d_{\text {spring }}=15.24 \mu \mathrm{m}$; Pomc neurons: $d_{\text {autmun }}=$ $14.56 \mu \mathrm{m}$ and $d_{\text {spring }}=15.31 \mu \mathrm{m}$; Rfrp neurons: $d_{\text {aut- }}$ mun $=15.93 \mu \mathrm{m}$ and $d_{\text {spring }}=16.11 \mu \mathrm{m}$; and Somatostatin neurons: $d_{\text {autmun }}=12.41 \mu \mathrm{m}$ and $d_{\text {spring }}=13.61$ $\mu \mathrm{m}$. A statistically significant difference in mean diameter between seasons was observed only for Kiss 1 cells. The final value given in the figures is the mean number of labeled neurons generated by the Abercrombie's correction in four animals per season.

semi-quantitative analysis of the in situ hybridization labeling intensity was performed as described previously (Klosen et al., 2013). Gray scale images (256 gray level tiff images) were taken on a Leica DMRB microscope (Leica Microsystems, Rueil-Malmaison, France) equipped with an Olympus DP50 digital camera (Olympus France, Rungis, France). All lighting parameters on the microscope and the settings of the Viewfinder Lite (Olympus) acquisition software were standardized to ensure consistent stable lighting throughout the image capture procedure. For each analyzed peptide, images of all autumn and spring animal brains were taken at the same time with the same settings. Images were taken with a $10 \times$ objective at a resolution of $1392 \times 1040$ pixels. A background image of the slide without a brain section was taken for each slide. This background image was subtracted from the corresponding sample image. The images were then analyzed using the ImageJ software. For Kiss1, Npy, Pomc, and Somatostatin analysis, both sides of the ventricle at the levels of the rostral, middle, and caudal ARC were sampled, while for Rfrp analysis the sampling concerned both sides of the $\mathrm{DMH} / \mathrm{VMH}$. Preliminary tests showed that analysis of 60 cells per brain was enough to provide a stable mean labeling intensity for each of the hypothalamic peptides analyzed. Labeling intensity was determined as the mean pixel gray value within a fixed-size circle of $50 \mu \mathrm{m}^{2}$ laid over 60 labeled cells randomly selected throughout the hypothalamic structure. For each animal, a mean value of labeling intensity was calculated from the 60 cells analyzed. For each peptide, labeling intensity was calculated as the mean pixel gray value of the four animals per season.

\section{Hormone assays}

Serum plasma testosterone was assayed at the Centre of Radioisotopes and Nuclear Medicine of Fes, 
Morocco, using a TESTO-CT2 Kit (Cis Bio International, Gif-sur-Yvette, France). This assay is based on the competition between testosterone and a fixed quantity of ${ }^{125}$-labeled testosterone for a limited number of binding sites on testosterone-specific antibody, and provides the quantitative in vitro determination of testosterone. The intra- and interassay values were $4.1 \%$ and $5.5 \%$, respectively.

\section{Methodological considerations and statistical analysis}

Values of cell count and labeling intensity for each neuropeptide were given as the mean of four jerboas per season. Comparisons were made between two groups of equal size, $n=4$. According to Zar (1999), when groups are equal then the $t$-test is fairly robust for moderate to large sample sizes. Thus, all comparisons were made with two-tailed $t$-tests with $n=6$ degrees of freedom and $P<0.05$ being considered statistically significant.

\section{RESULTS}

\section{Seasonal variations in male jerboa's testicular activity}

Male jerboas captured in spring had significantly larger testes $(2.83 \pm 0.3 \mathrm{~g} ; n=4)$ and higher plasma testosterone levels (5.11 $\pm 0.76 \mathrm{ng} / \mathrm{L} ; n=4)$ than animals captured in autumn (testes weight was $0.56 \pm$ $0.13 \mathrm{~g}$; plasma testosterone was $0.71 \pm 0.17 \mathrm{ng} / \mathrm{L} ; n$ $=4$ ). These results confirm the sexual spring activation and autumn quiescence of the captured male jerboas.

\section{Neuroanatomical distribution of neurons expressing Rfrp, Kiss1, Pomc, Somatostatin, or Npy}

Whatever the season, neurons expressing Rfrp mRNA were found only in the DMH/VMH area (Fig. 1A). Neurons expressing Kiss1 (Fig. 2A), Pomc (Fig. 3A), Somatostatin (Fig. 4A), and Npy (Fig. 5A) mRNA were detected along the rostral, middle, and caudal ARC. Although not shown here, Kiss 1 neurons were also observed in the AVPV and Somatostatin neurons in the anterior periventricular hypothalamic area and ventromedial hypothalamic nucleus. The expected neuroanatomical distribution of these neuropeptides, as well as the absence of signal with the sense probes, confirms the specificity of the heterologous probes used to hybridize jerboa's ARC genes.

\section{Seasonal variations in Rfrp and Kiss 1 gene expression}

Seasonal variations of Rfrp expression in the $\mathrm{DMH} /$ VMH (Fig. 1A) and Kiss1 in the ARC (Fig. 2A) were
A
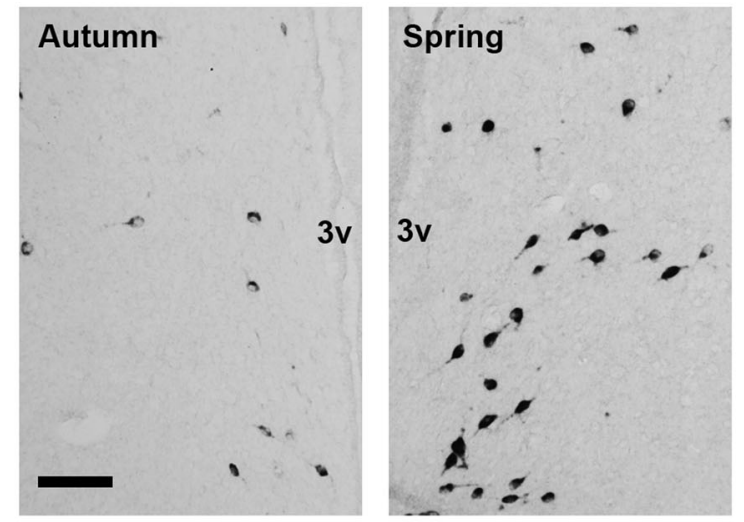

B

C
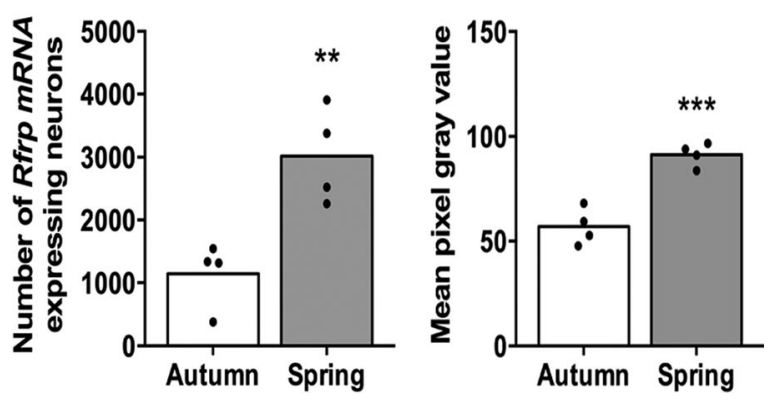

Figure 1. Seasonal variation in Rfrp gene expression in the hypothalamus of male jerboas. A: Representative pictures showing nonradioactive in situ hybridization of Rfrp mRNA in neurons of the dorso/ventromedial hypothalamus of jerboas captured in autumn (left panel) or spring (right panel), 3v: third ventricle. B: Estimation of the total number of Rfrp mRNA-expressing neurons per animal throughout the dorso/ventromedial hypothalamus in autumn and spring jerboas. C: semi-quantification of labeling intensity of Rfrp mRNA measured in individual neurons in the hypothalamus of spring and autumn jerboas; for each animal, a mean pixel gray value is calculated from 60 neurons. Dots show the individual values for each animal and bars the mean value for each group $\left(n=4 ;{ }^{*} P<0.01\right.$ and ${ }^{*} * P<0.001$ as compared to autumn value). Scale bar $=50 \mu \mathrm{M}$.

examined in jerboas captured in May or November. The number of Rfrp mRNA-expressing neurons was significantly higher in spring compared to autumn animals $(P$ $=0.006 ; t=-4,066$; Fig. 1B). Furthermore, analysis of the labeling intensity per neuron indicated that the level of Rfrp mRNA per neuron is significantly higher in spring compared to autumn animals $(P=0.0005 ; t=$ -6,595; Fig. 1C). The number of ARC Kiss 1 mRNAexpressing neurons was not significantly different between spring and autumn animals $(P=0.8 ; t=-$ 0,217; Fig. 2B). However, analysis of labeling intensity per neuron indicated a significantly higher level of Kiss 1 
A

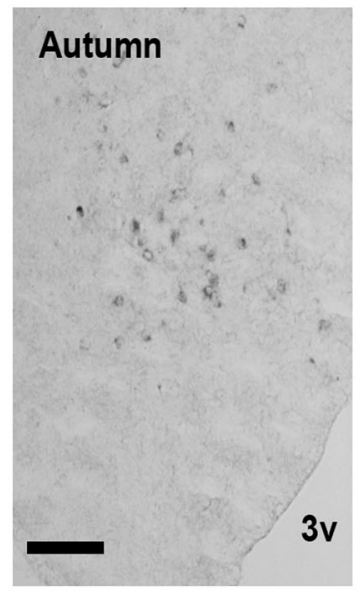

B

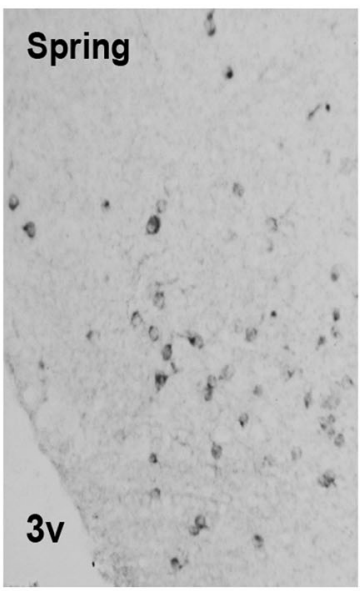

C

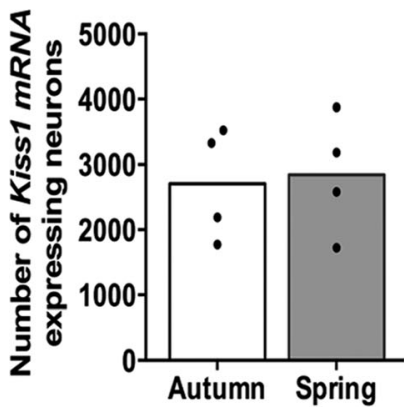

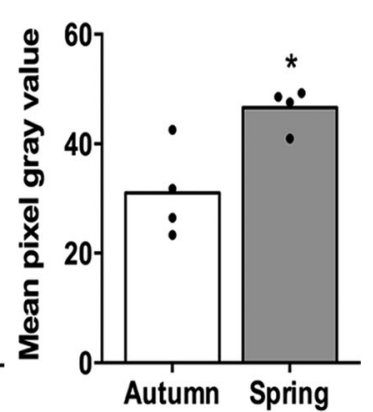

Figure 2. Seasonal variation in Kiss1 gene expression in the hypothalamus of male jerboas. A: Representative pictures showing nonradioactive in situ hybridization of Kiss 1 mRNA in neurons of arcuate nucleus (ARC) of jerboas captured in autumn (left panel) or spring (right panel), $3 \mathrm{v}$ : third ventricle. B: Estimation of the total number of Kiss 1 mRNA-expressing neurons per animal throughout the ARC in autumn and spring jerboas. C: semiquantification of the labeling intensity of Kiss 1 mRNA measured in individual neurons in the ARC of spring and autumn jerboas; for each animal, a mean pixel gray value is calculated from 60 neurons. Dots show the individual values for each animal and bars the mean value for each group $\left(n=4\right.$; ${ }^{\star} P<0.05$ as compared to autumn value). Scale bar $=50 \mu \mathrm{M}$.

mRNA in spring as compared to autumn animals $(P=$ $0.01 ; t=-3,357$; Fig. 2C).

\section{Seasonal variations in Pomc, Somatostatin, and Npy gene expression}

Expression of genes coding for the anorexigenic POMC (Fig. 3A) and somatostatin (Fig. 4A) and the orexigenic NPY (Fig. 5A) was analyzed in the ARC of spring and autumn jerboas. The number of neurons expressing Pomc mRNA $(P=0.004, t=-4,346$; Fig. $3 \mathrm{~B})$ or Somatostatin mRNA ( $P=0.01 ; t=-3,531$; Fig.

A
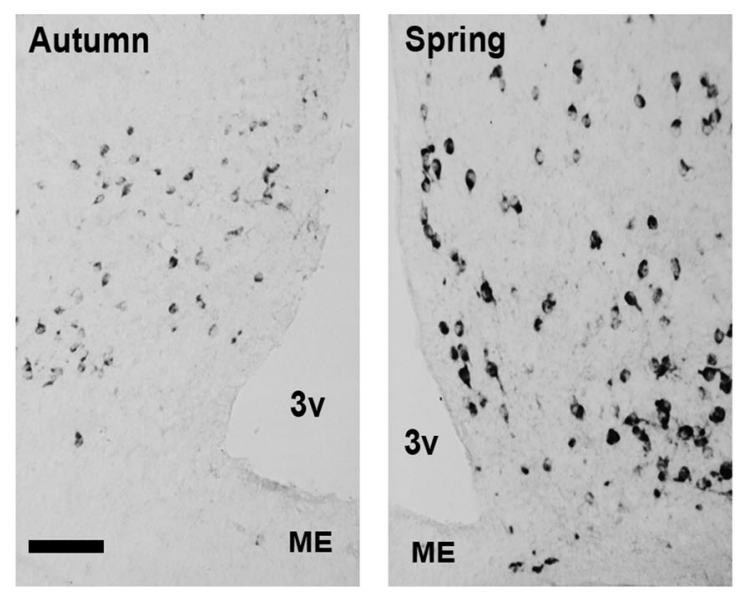

B

C
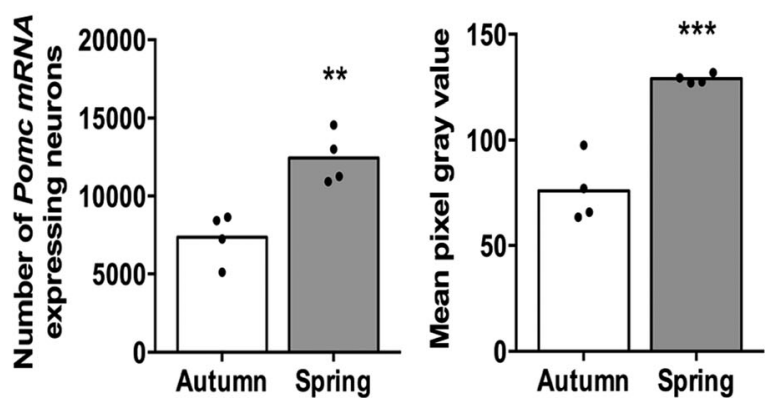

Figure 3. Seasonal variation in Pomc gene expression in the hypothalamus of male jerboas. A: Representative pictures showing nonradioactive in situ hybridization of pomc mRNA in neurons of arcuate nucleus (ARC) of jerboas captured in autumn (left panel) or spring (right panel), 3v: third ventricle, ME: median eminence. B: Estimation of the total number of Pomc mRNAexpressing neurons per animal throughout the ARC in autumn and spring jerboas. C: semi-quantification of the labeling intensity of Pomc mRNA measured in individual neurons in the ARC of spring and autumn jerboas; for each animal, a mean pixel gray value is calculated from 60 neurons. Dots show the individual values for each animal and bars the mean value for each group ( $n$ $=4 ;{ }^{*} P<0.01$ and ${ }^{* *} P<0.001$ as compared to autumn value). Scale bar $=50 \mu \mathrm{M}$.

4B) was markedly higher in spring as compared to autumn. Similarly, the intensity of hybridization signal per neuron was higher in spring as compared to autumn for both Pomc ( $P=0.0005, t=-6,723$; Fig. $3 \mathrm{C})$ and Somatostatin $(P=0.02 ; t=-3,022 ;$ Fig. $4 \mathrm{C})$ neurons. Analysis of seasonal variations of the mean number of Npy mRNA-expressing neurons $(P=0.1 ; t=$ $1,809$; Fig. $5 \mathrm{~B})$ as well as the mean staining intensity per neuron $(P=0.1, t=1,648$; Fig. $5 \mathrm{C})$ indicates no significant variations between either season. 
A

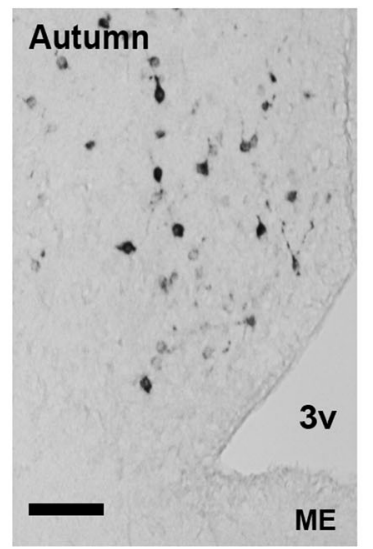

B

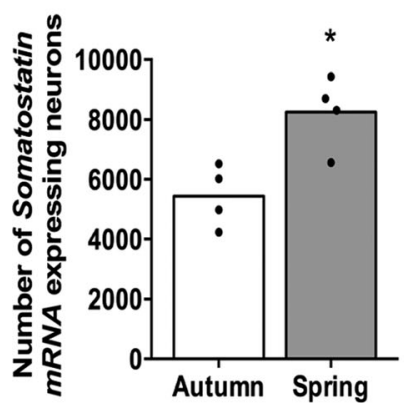

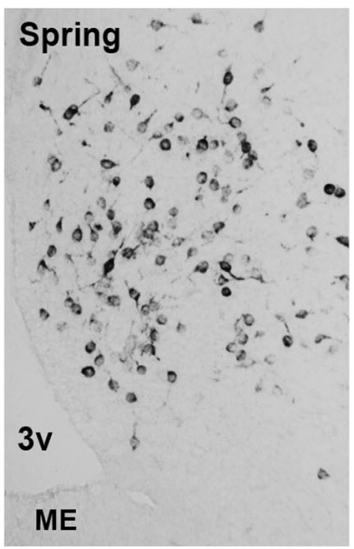

C

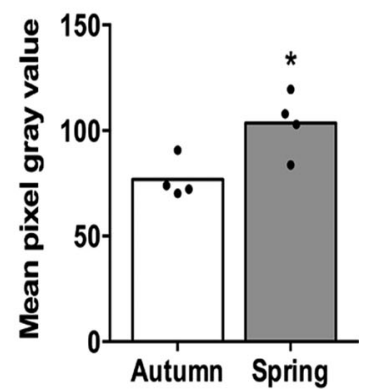

Figure 4. Seasonal variation in Somatostatin gene expression in the hypothalamus of male jerboas. A: Representative pictures showing nonradioactive in situ hybridization of Somatostatin mRNA in neurons of arcuate nucleus (ARC) of jerboas captured in autumn (left panel) or spring (right panel), 3v: third ventricle, ME: median eminence. B: Estimation of the total number of Somatostatin mRNA-expressing neurons per animal throughout the ARC in autumn and spring jerboas. C: semi-quantification of the labeling intensity of Somatostatin mRNA labeling measured in individual neurons in the ARC of spring and autumn jerboas; for each animal, a mean pixel gray value is calculated from 60 neurons. Dots show the individual values for each animal and bars the mean value for each group $\left(n=4\right.$; ${ }^{\star} P<0.05$ as compared to autumn value). Scale bar $=50 \mu \mathrm{M}$.

\section{DISCUSSION}

This study is the first to report seasonal regulation of genes encoding several hypothalamic peptides involved in the central control of reproduction and energy balance in a wild rodent species. Notably, our results indicate a coordinated springtime increase in the expression of four peptides involved in activation of reproduction and food intake inhibition in the desert jerboa.

The jerboa is a desert rodent of the family of North African Dipodidae. It is a wild animal that lives in an environment characterized by large fluctuations in

A
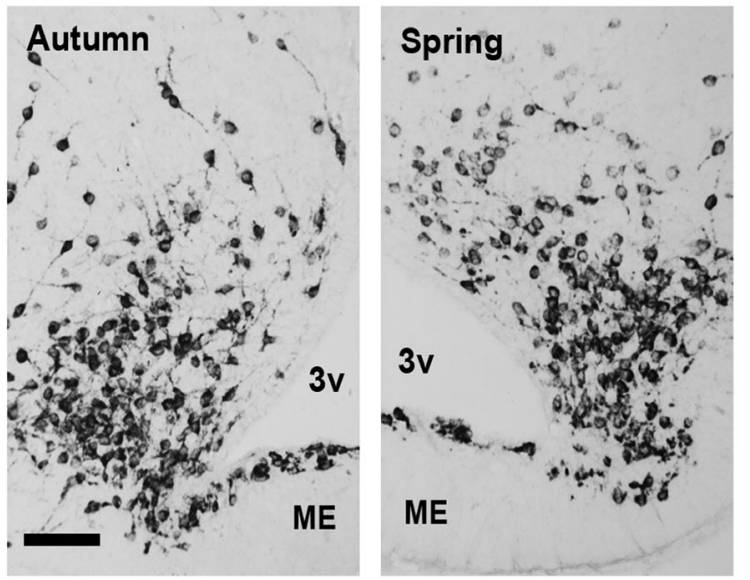

B

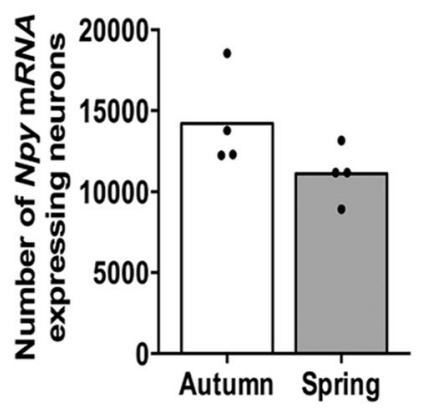

C

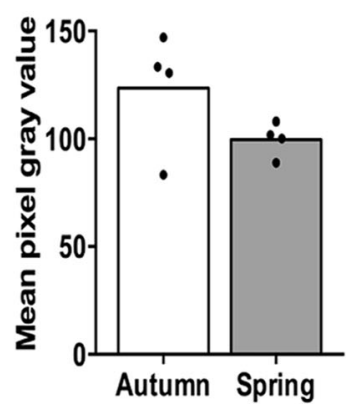

Figure 5. Seasonal variation in Npy gene expression in the hypothalamus of male jerboas. A: Representative pictures showing nonradioactive in situ hybridization of Npy mRNA in neurons of arcuate nucleus (ARC) of jerboas captured in autumn (left panel) or spring (right panel), 3v: third ventricle, ME: median eminence. B: Estimation of the total number of Npy mRNA-expressing neurons per animal throughout the ARC in autumn and spring jerboas. C: semi-quantification of the labeling intensity of Npy mRNA labeling measured in individual neurons in the ARC of spring and autumn jerboas; for each animal, a mean pixel gray value is calculated from 60 neurons. Dots show the individual values for each animal and bars the mean value for each group ( $n$ 4). Scale bar $=50 \mu \mathrm{M}$.

external temperature, food, and water supply. Therefore, it appears to be a better model compared to other laboratory animals to assess the possible link between the seasonal regulation of hypothalamic peptides involved in the central control of reproduction and metabolism. The jerboa is a species known to develop interesting strategies to ensure its adaptation to seasonal changes. In its natural environment, it anticipates seasonal stressors and adjusts its reproductive and metabolic axes accordingly. In autumn, the male jerboa shuts down its reproduction, as seen by lower $\mathrm{GnRH}$ immunoreactivity (El Ouezzani et al., 2000) and reduced testicular activity (El Qandil et al., 2004; this study). In 
the female jerboa, body weight (El Ouezzani et al., 2011) and food intake (Talbi et al., unpublished data) increase in autumn-winter in order to anticipate the upcoming winter hibernation, a state accompanied by hypothermia and low metabolism (El Hilali and Veillat, 1975; El Ouezzani et al., 2001; Malan, 2014). In contrast, when favorable conditions return in spring, these physiological states are reversed, with the reactivation of the reproductive axis (El Ouezzani et al., 2000; El Qandil et al., 2004; this study) and a decrease in body weight and food intake (El Ouezzani et al., 2011; Talbi et al., unpublished data). The present work investigated whether expression of genes encoding peptides regulating reproduction ( $\mathrm{Kp}$ and RFRP-3) and energy balance (POMC, somatostatin, and NPY) are altered by seasonal changes of the environment in the male jerboa.

Expression of neuropeptides regulating reproduction is influenced by the seasonal environment. The Rfrp mRNA level in the DMH/VMH was higher in spring as compared to autumn, seen in both the mean number of Rfrp mRNA-expressing neurons and the mean staining intensity of individual neurons. Kiss 1 gene analysis in the ARC revealed that the labeling intensity per neuron was significantly increased in spring compared to autumn; however, no apparent significant difference in the number of Kiss1 mRNA-expressing neurons was observed between the two seasons. We previously reported that the number of Kp-immunoreactive (ir) neurons in the ARC of male jerboas is increased in spring as compared to autumn (Janati et al., 2013). This discrepancy between the seasonal variation in Kpir and Kiss1 mRNA-expressing neurons may be caused by differences in the sensitivity of the technical approaches. Alternatively, it may result from seasonal variation in post-transcriptional processing since Kiss 1 mRNA is always detected in ARC neurons whatever the season, but the synthesis rate reflected by the level of Kiss1 mRNA per neuron displays seasonal variation. The coincident upregulation of mRNA levels and immunostaining clearly shows that the increase in $\mathrm{Kp}$ and RFRP-3 immunostaining is not due to lack of secretion and neuronal accumulation of these peptides, but the synthesis of these neuropeptides is increased in spring. Based on these findings, it is tempting to speculate that in the jerboa, like in other seasonal rodents, the autumn and winter increases nighttime melatonin production (Lakhdar-Ghazal et al., 1992) and inhibits Rfrp and Kiss 1 gene expression via a reduction of thyroid hormone synthesis in the basal hypothalamus (Revel et al., 2006a,b, 2008; Barrett et al., 2007; Ubuka et al., 2012; Klosen et al., 2013). The difference in the amplitude of the seasonal variations between Rfrp and Kiss 1 gene expression could result from a differential peptide response to the sex steroid feedback. Indeed, the negative feedback exerted by sex steroids on ARC Kp neurons is well documented in many species (Smith et al., 2005; Revel et al., 2006; Kauffman et al., 2007; Ansel et al., 2010), whereas the sex steroid feedback on RFRP-3 neurons is absent in rat (Quennell et al., 2010), sheep (Smith et al., 2008), Syrian (Revel et al., 2008) and Siberian (Ubuka et al., 2012) hamsters, or moderate in mice (Molnár et al., 2011; Poling et al., 2012).

Altogether, our results indicate that in spring there is an increased synthesis of both RFRP-3 and $\mathrm{Kp}$ in the jerboa's hypothalamus that correlates with a gonadal activation. $\mathrm{Kp}$ is well established as a potent activator of $\mathrm{GnRH}$ release in mammalian species (Pinilla et al., 2012, for review) and its increase in spring may drive the seasonal activation of jerboa's reproduction, as already demonstrated for other seasonal species like the Syrian (Revel et al., 2006a) and Siberian (Mason et al., 2007) hamsters and sheep (Caraty et al., 2007). Preliminary data obtained in the male jerboa indeed confirm that a single icv injection of 3 nmole of $\mathrm{Kp}$ increases testosterone production in both spring and autumn (Talbi et al., in preparation). In contrast, the effect of RFRP-3 on reproductive activity is controversial, being inhibitory in sheep (Clarke et al., 2008), rat (Johnson et al., 2007), and mice (Ducret et al., 2009) but stimulatory in the male Syrian (Ancel et al., 2012) and short-day-adapted Siberian hamsters (Ubuka et al., 2012). The marked springtime increase in Rfrp expression in sexually active jerboas is in line with what has been observed in other seasonal species (Simonneaux and Ancel, 2012) and suggests a potential activatory effect of RFRP-3 on the reproductive axis of male jerboa.

The seasonal regulation of genes encoding peptides considered as key molecules in the control of feeding behavior was also investigated in the male jerboa. Expression of the gene coding for the anorexigenic POMC, seen in both the number of labeled neurons and the mean staining intensity of individual POMC neurons in the hypothalamus, was markedly increased in spring as compared to autumn. In the Siberian hamster, ARC Pomc gene expression was also reported higher in longday as compared to short-day-adapted animals (Mercer et al., 2000). Seasonal variation in Pomc expression was also reported in the ewe, where the number of POMC cells and the density of grains per cell increased during the anestrus season (Clarke et al., 2000). $\alpha$ $\mathrm{MSH}$, one of the peptides processed from POMC, is a strong inhibitor of food intake (Fan et al., 1997; Brown et al., 1998; McMinn et al., 2000). Therefore, our observation of lower Pomc expression in autumn jerboas could lead to a reduced synthesis in $\alpha-M S H$, which 
could account for the increase in body weight observed at this time of the year. Somatostatin is a hypothalamic neuropeptide known for inhibiting the secretion of the pituitary growth hormone (Vale et al., 1972; Brazeau et al., 1974; Rogers et al., 1988) and food intake in rats and baboons (Lotter et al., 1981). Recent studies have reported its involvement in the seasonal regulation of body mass and metabolism. Indeed, Siberian hamsters adapted to a short photoperiod display a decrease in body weight associated with an increase in Somatostatin gene expression (Herwig et al., 2012; Dumbell et al., 2015). In the present study, we observed a significant increase in Somatostatin gene expression in spring as compared to autumn, which is in line with the reported decrease in the jerboa's body weight in spring and summer (El Ouezzani et al., 2011). Therefore, Siberian hamster and jerboa appear to display opposite but coordinated seasonal variations in both Somatostatin gene expression and body weight. Regarding NPY expression in the jerboa's ARC, the level of Npy mRNA was found very strong in both seasons. No significant variation between spring and autumn in the number of NPY cells or the staining intensity of individual NPY neurons was observed. A similar lack of photoperiodic variation in NPY expression was previously reported in the Siberian hamster (Mercer et al., 2000). By contrast in the ewe, both the number of NPY-ir cells (Skinner and Herbison, 1997) and the level of Npy gene expression in the ARC (Clarke et al., 2000) were reported to be higher in May as compared to September, and were suggested to be related to a seasonal regulation of food intake. Besides its strong orexigenic function, studies have reported its involvement in the regulation of GnRH neurons activity (Li et al., 1999). NPY can either activate (Kalra and Crowley, 1984; Khorram et al., 1987) or inhibit (Khorram et al., 1987; McDonald et al., 1989; Kaynard et al., 1990) the reproductive axis, with possible environment and species dependence.

Two genes encoding neuropeptides involved in food intake and body weight regulation, Pomc and Somatostatin, thus display a strong reduction of expression in autumn. We recently reported in the Siberian hamster that the seasonal variation in Somatostatin gene expression, like Kiss 1 and Rfrp, is driven by a melatonindependent TSH mechanism (Klosen et al., 2013). Further studies should examine whether the parallel reduction in Kiss1, Rfrp, Somatostatin but also Pomc gene expression observed in autumn in jerboa is related to similar melatonin-dependent mechanisms. Additionally, peptide interaction cannot be excluded to explain such correlated seasonal variations. Fu and van den Pol (2010) reported Kp fiber projection to POMC neurons and showed a direct excitation of POMC neurons by $\mathrm{Kp}$, suggesting a possible indirect modulation of food intake by Kp through POMC neurons, while a direct role of $\mathrm{Kp}$ in the regulation of metabolism has also been suggested (De Bond and Smith, 2014, for review). On the other hand, there is a bidirectional communication between somatostatin and POMC neurons since somatostatin receptors are located on POMC ARC neurons and POMC neurons project to a majority of somatostatin neurons in the periventricular nucleus, indicating that somatostatin effects on growth could be under the influence of melanocortins (Fodor et al., 1998).

In conclusion, this study reports a general springtime activation of genes encoding hypothalamic peptides involved in the activation of reproduction and inhibition of food intake in the male jerboa. These variations are in line with the seasonal physiology of the jerboa, since genes encoding RFRP and $K p$ are both increased in spring when the animals become sexually active and similarly genes encoding the anorexigenic POMC and somatostatin are also increased in spring when the animals reduce their body weight. Based on these results, it is hypothesized that reproduction and energy balance are modulated oppositely in the jerboa. The increase in body weight during autumn could be a long-term anticipatory adaptive process allowing the animal's preparation for the upcoming reproductive activity in early spring. The possibility that the seasonal changes in melatonin production orchestrate this coordinated seasonal variation in neuropeptides should be considered. Furthermore, the possible interactions among these neuropeptides to synchronize the balance between the seasonal reproduction and the metabolic activity should also be investigated.

\section{ACKNOWLEDGMENTS}

Authors thank Dr. Matthew Beymer for English proofreading and Dr. Andre Malan for assistance with statistical analysis. Rajae Talbi's stays in Strasbourg were supported by the PICS (CNRST-Maroc / CNRS-France) Volubilis \# 5631 and the French-Moroccan GDRI NeurO and Neuromed.

\section{CONFLICT OF INTEREST}

The authors declare no conflicts of interest.

\section{ROLE OF AUTHORS}

All authors had full access to the data in the study and take responsibility for the integrity of the data and the accuracy of the data analysis. Study concept and design: RT, VS, SEO. Acquisition of data: RT, PK, MP. 
Analysis and interpretation of data: RT, VS, PK, SEO. Drafting of article: RT, VS, SEO. Revision of the article for important intellectual content: RT, VS, PK, SEO. Statistical analysis: RT, PK. Obtained funding: VS, SEO. Technical and material support: RT, PK, MP. Study supervision: VS, SEO.

\section{LITERATURE CITED}

Abercrombie M. 1946. Estimation of nuclear population from microtome sections. Anat Rec 94:239-247.

Ancel C, Bentsen AH, Sébert M-E, Tena-Sempere M, Mikkelsen JD, Simonneaux V. 2012. Stimulatory effect of RFRP-3 on the gonadotrophic axis in the male Syrian hamster: the exception proves the rule. Endocrinology 153:1352-1363.

Andjus RK, El Hilali M, Veillat JP, Baddouri K. 1974. Tolerance of one species of jerboa (Jaculus orientalis) to prolonged exposure to deep hypothermia. J Physiol (Paris) 68:531542.

Ansel L, Bolborea M, Bentsen AH, Klosen P, Mikkelsen JD, Simonneaux V. 2010. Differential regulation of kiss 1 expression by melatonin and gonadal hormones in male and female Syrian hamsters. J Biol Rhythms 25:81-91.

Bai FL, Yamano M, Shiotani Y, Emson PC, Smith AD, Powell JF, Tohyama M. 1985. An arcuato-paraventricular and dorsomedial hypothalamic neuropeptide Y-containing system which lacks noradrenaline in the rat. Brain Res 331: 172-175.

Barrett P, Bolborea M. 2012. Molecular pathways involved in seasonal body weight and reproductive responses governed by melatonin. J Pineal Res 52:376-388.

Barrett P, Ebling FJP, Schuhler S, Wilson D, Ross AW, Warner A, Jethwa P, Boelen A, Visser TJ, Ozanne DM, Archer ZA, Mercer JG, Morgan PJ. 2007. Hypothalamic thyroid hormone catabolism acts as a gatekeeper for the seasonal control of body weight and reproduction. Endocrinology 148:3608-3617.

Brazeau P, Rivier J, Vale W, Guillemin R. 1974. Inhibition of growth hormone secretion in the rat by synthetic somatostatin. Endocrinology 94:184-187.

Brown KS, Gentry RM, Rowland NE. 1998. Central injection in rats of alpha-melanocyte-stimulating hormone analog: effects on food intake and brain Fos. Reg Peptides 78: 89-94.

Caraty A, Smith JT, Lomet D, Ben said S, Morrissey A, Cognie J, Doughton B, Baril G, Briant C and IJC. 2007. Kisspeptin synchronizes preovulatory surges in cyclical ewes and causes ovulation in seasonally acyclic ewes. Endocrinology 148:5258-5267.

Clarke IJ, Scott CJ, Rao A, Pompolo S, Barker-Gibb ML. 2000. Seasonal changes in the expression of neuropeptide $Y$ and pro-opiomelanocortin mRNA in the arcuate nucleus of the ovariectomized ewe: Relationship to the seasonal appetite and breeding cycles. J Neuroendocrinol 12: 1105-1111.

Clarke IJ, Sari IP, Qi Y, Smith JT, Parkington HC, Ubuka T, Iqbal J, Li Q, Tilbrook A, Morgan K, Pawson AJ, Tsutsui K, Millar RP, Bentley GE. 2008. Potent action of RFamiderelated peptide-3 on pituitary gonadotropes indicative of a hypophysiotropic role in the negative regulation of gonadotropin secretion. Endocrinology 149:5811-5821.

Danguir J. 1988. Food intake in rats is increased by intracerebroventricular infusion of the somatostatin analogue SMS 201-995 and is decreased by somatostatin antiserum. Peptides 9:211-213.
Dardente H. 2012. Melatonin-dependent timing of seasonal reproduction by the pars tuberalis: pivotal roles for long daylengths and thyroid hormones. J Neuroendocrinol 24: 249-66.

De Bond JAP, Smith JT. 2014. Kisspeptin and energy balance in reproduction. Reproduction 147:R53-R63.

Dhillo WS, Chaudhri OB, Patterson M, Thompson EL, Murphy KG, Badman MK, McGowan BM, Amber V, Patel S, Ghatei MA, Bloom SR. 2005. Kisspeptin-54 stimulates the hypothalamic-pituitary gonadal axis in human males. J Clin Endo Metab 90:6609-6615.

Ducret E, Anderson GM, Herbison AE. 2009. RFamide-related peptide-3, a mammalian gonadotropin-inhibitory hormone ortholog, regulates gonadotropin-releasing hormone neuron firing in the mouse. Endocrinology 150:2799-2804.

Dumbell R, Scherbarth F, Diedrich V, Schmid H, Steinlechner S, Barrett P. 2015. Somatostatin agonist pasireotide promotes a physiological state resembling short-day acclimation in the photoperiodic male Siberian hamster (Phodopus sungorus). J Neuroendocrinol 27:588-599.

Ebling FJ, Lincoln GA. 1987. Beta-endorphin secretion in rams related to season and photoperiod. Endocrinology 120: 809-818.

El Hilali M VJP. 1975. Jaculus orientalis: a true hibernator. Mammalia 39:402-404.

El Ouezzani S, Tramu G, Magoul. R. 2000. The GonadotropinReleasing Hormone neurosecretory system of the Jerboa (Jaculus orientalis) and its seasonal variations. J Neuroendocrinol 12:1205-1212.

El Ouezzani S, Tramu G, Magoul R, Lafon P. 2001. Neuropeptide $Y$ gene expression in the jerboa arcuate nucleus: modulation by food deprivation and relationship with hibernation. Neurosci Lett 305:21-24.

El Ouezzani S, Tramu G, Magoul R. 2005. Seasonal variations of the beta-endorphin neuronal system in the mediobasal hypothalamus of the jerboa (Jaculus orientalis). Neurosci Lett 376:107-110.

El Ouezzani S, Janati IA, Magoul R, Pévet P, Saboureau M. 2011. Overwinter body temperature patterns in captive jerboas (Jaculus orientalis): influence of sex and group. J Comp Physiol 181:299-309.

El Qandil S, Chakir J, Moussaouiti R, El Oukouchoud R, Rami N, Benjelloun W, Lakhdar-Ghazal N. 2004. Role of the pineal gland and melatonin in the photoperiodic control of hypothalamic gonadotropin-releasing hormone in the male jerboa (Jaculus orientalis), a desert rodent. Brain Res Bull 64:371-380.

Evans JJ, Anderson GM. 2012. Balancing ovulation and anovulation: integration of the reproductive and energy balance axes by neuropeptides. Hum Reprod 18:313-332.

Fan W, Boston BA, Kesterson RA, Hruby VJ, Cone RD. 1997. Role of melanocortinergic neurons in feeding and the agouti obesity syndrome. Nature 385:165-168.

Fang Y, Kelly MJ, Rønnekleiv OK. 1998. Proopiomelanocotin (POMC) mRNA-expression: distribution and regionspecific down-regulation by chronic morphine in female guinea pig hypothalamus. Mol Brain Res 55:1-8.

Fehlmann D, Langenegger D, Schuepbach E, Siehler S, Feuerbach D, Hoyer D. 2000. Distribution and characterisation of somatostatin receptor mRNA and binding sites in the brain and periphery. J Physiol (Paris) 94:265-281.

Fernandez-Fernandez R, Martini AC, Navarro VM, Castellano JM, Dieguez C, Aguilar E, Pinilla L, Tena-Sempere M. 2006. Novel signals for the integration of energy balance and reproduction. Mol Cell Endocrinol 254:127-132.

Fodor M, Csaba Z, Epelbaum J, Vaudry H, Jegou S. 1998. Interrelations between hypothalamic somatostatin and proopiomelanocortin neurons. J Neuroendocrinol 10:75-78. 
Fu LY, van den Pol AN. 2010. Kisspeptin directly excites anorexigenic proopiomelanocortin neurons but inhibits orexigenic neuropeptide $\mathrm{Y}$ cells by an indirect synaptic mechanism. J Neurosci 30:10205-10219.

Garcia-Garcia RM. 2012. Integrative Control of Energy Balance and Reproduction in Females. ISRN Vet Sci 2012: 121389.

Ghobrial LI, Hodieb AS. 1973. Climate and seasonal variations in the breeding of the desert jerboa, Jaculus jaculus, in the Sudan. J Reprod Fertil 19:221-233.

Gottsch ML, Cunningham MJ, Smith JT, Popa SM, Acohido B V, Crowley WF, Seminara S, Clifton DK, Steiner R. 2004. A role for kisspeptins in the regulation of gonadotropin secretion in the mouse. Endocrinology 145:4073-4077.

Guillemin R, Gerich JE. 1976. Somatostatin: physiological and clinical significance. Annu Rev Med 27:379-388.

Hazlerigg D, Simonneaux V. 2014. Seasonal regulation of reproduction in Mammals. In: Plant TM, Zeleznik AJ, editors. Knobil and Neill's physiology of reproduction, 4th ed. Amsterdam, Academic Press, Elsevier. Chapter 34, pp 1575-1604.

Herwig A, Petri I, Barrett P. 2012. Hypothalamic gene expression rapidly changes in response to photoperiod in juvenile Siberian hamsters (Phodopus sungorus). J Neuroendocrinol 24:991-998.

Hill JW, Elmquist JK, Elias CF. 2008. Hypothalamic pathways linking energy balance and reproduction. Am J Physiol 294:E827-E832.

Janati A, Talbi R, Klosen P, Mikkelsen JD, Magoul R, Simonneaux V, El Ouezzani S. 2013. Distribution and seasonal variation in hypothalamic RF-amide peptides in a semi-desert rodent, the jerboa. J Neuroendocrinol 25: 402-411.

Johansson O, Hokfelt T, Elde RP. 1984. Immunohistochemical distribution of somatostatin-like immunoreactivity in the central nervous system of the adult rat. Neuroscience 13:265-339.

Johnson MA, Tsutsui K, Fraley GS. 2007. Rat RFamide-related peptide-3 stimulates $\mathrm{GH}$ secretion, inhibits $\mathrm{LH}$ secretion, and has variable effects on sex behavior in the adult male rat. Horm Behav 51:171-180.

Kalra SP, Crowley WR. 1984. Norepinephrine-like effects of neuropeptide $\mathrm{Y}$ on $\mathrm{LH}$ release in the rat. Life Sci 35: 1173-1176.

Kauffman AS, Gottsch ML, Roa J, Byquist AC, Crown A, Clifton DK, Hoffman GE, Steiner RA, Tena-Sempere M. 2007. Sexual differentiation of Kiss 1 gene expression in the brain of the rat. Endocrinology 148:1774-1783.

Kaynard AH, Pau KYF, Hess DL, Spies HG. 1990. Third-ventricular infusion of neuropeptide $Y$ suppresses luteinizing hormone secretion in ovariectomized rhesus macaques. Endocrinology 127:2437-2444.

Khorram O, Pau KY, Spies HG. 1987. Bimodal effects of neuropeptide $Y$ on hypothalamic release of gonadotropinreleasing hormone in conscious rabbits. Neuroendocrinology 45:290-297.

Klosen P, Maessen X, van den Bosch de Aguilar P. 1993. PEG embedding for immunocytochemistry: application to the analysis of immunoreactivity loss during histological processing. J Histochem Cytochem 41:455-463.

Klosen P, Sebert ME, Rasri K, Laran-Chich MP, Simonneaux V. 2013. TSH restores a summer phenotype in photoinhibited mammals via the RF-amides RFRP3 and kisspeptin. FASEB J 27:2677-2686.

Kriegsfeld LJ, Mei DF, Bentley GE, Ubuka T, Mason AO, Inoue K, Ukena K, Tsutsui K, Silver R. 2006. Identification and characterization of a gonadotropin-inhibitory system in the brains of mammals. Proc Natl Acad Sci U S A 103: 2410-2415.

Kriegsfeld LJ, Gibson EM, Williams WP, Zhao S, Mason AO, Bentley GE, Tsutsui K. 2010. The roles of RFamiderelated peptide-3 in mammalian reproductive function and behaviour. J Neuroendocrinol 22:692-700.

Lakhdar-Ghazal N, Vivien-Roels B, Pevet P. 1992. Seasonal variations in pineal 5-methoxytryptophol (5-ML) concentrations and in the daily pattern of pineal 5-ML and melatonin in the desert rodent Jaculus orientalis: Effect of prolonged illumination during the night. J Pineal Res 13: 28-35.

Lakhdar-Ghazal N, Pévet P, Oukouchoud R. 1995. Seasonal variation in NPY immunoreactivity in the suprachiasmatic nucleus of the jerboa (Jaculus orientalis), a desert hibernator. Neurosci Lett 193:49-52.

Leibowitz SF. 1991. Brain neuropeptide Y: An integrator of endocrine, metabolic and behavioral processes. Brain Res Bull 27:333-337.

Li C, Chen P, Smith MS. 1999. Morphological evidence for direct interaction between arcuate nucleus neuropeptide $Y$ (NPY) neurons and gonadotropin-releasing hormone neurons and the possible involvement of NPY Y1 receptors. Endocrinology 140:5382-5390.

Lotter EC, Krinsky R, McKay JM, Treneer CM, Porter D, Woods SC. 1981. Somatostatin decreases food intake of rats and baboons. J Comp Physiol Psychol 95:278-287.

Malan A. 2014. The evolution of mammalian hibernation: lessons from comparative acid-base physiology. Integr Comp Biol 54:484-496.

Mason AO, Greives TJ, Scotti M-AL, Levine J, Frommeyer S, Ketterson ED, Demas GE, Kriegsfeld LJ. 2007. Suppression of kisspeptin expression and gonadotropic axis sensitivity following exposure to inhibitory day lengths in female Siberian hamsters. Horm Behav 52:492-498.

McDonald JK, Lumpkin MD, DePaolo LV. 1989. Neuropeptide$Y$ suppresses pulsatile secretion of luteinizing hormone in ovariectomized rats: Possible site of action. Endocrinology 125:186-191.

McMinn JE, Wilkinson CW, Havel PJ, Woods SC, Schwartz MW. 2000. Effect of intracerebroventricular alpha-MSH on food intake, adiposity, c-Fos induction, and neuropeptide expression. Am J Physiol 279:R695-R703.

Mercer JG, Moar KM, Ross AW, Hoggard N, Morgan PJ. 2000. Photoperiod regulates arcuate nucleus POMC, AGRP, and leptin receptor mRNA in Siberian hamster hypothalamus. Am J Physiol 278:R271-R281.

Messager S, Chatzidaki EE, Ma D, Hendrick AG, Zahn D, Dixon J, Thresher RR, Malinge I, Lomet D, Carlton MBL, Colledge WH, Caraty A, Aparicio SJR. 2005. Kisspeptin directly stimulates gonadotropin-releasing hormone release via G protein-coupled receptor 54. Proc Natl Acad Sci U S A 102:1761-1766.

Mikkelsen JD, Simonneaux V. 2009. The neuroanatomy of the kisspeptin system in the mammalian brain. Peptides 30 : 26-33.

Molnár CS, Kalló I, Liposits Z, Hrabovszky E. 2011. Estradiol downregulates RF-amide-related peptide (RFRP) expression in the mouse hypothalamus. Endocrinology 152:1684-1690.

Morley JE. 1987. Neuropeptide regulation of appetite and weight. Endocrine Rev 8:256-287.

Murphy B, Nunes CN, Ronan JJ, Harper CM, Beall MJ, Hanaway M, Fairhurst AM, Van Der Ploeg LHT, Maclntyre DE, Mellin TN. 1998. Melanocortin mediated inhibition of feeding behavior in rats. Neuropeptides 32:491-497.

Paxinos G, Watson C. 2005. The rat brain in stereotaxic coordinates,. $5^{\text {th }}$ ed. New York: Elsevier Academic Press. 
Pineda R, Garcia-Galiano D, Sanchez-Garrido MA, Romero M, Ruiz-Pino F, Aguilar E, Dijcks FA, Blomenröhr M, Pinilla L, van Noort PI, Tena-Sempere M. 2010. Characterization of the inhibitory roles of RFRP3, the mammalian ortholog of $\mathrm{GnlH}$, in the control of gonadotropin secretion in the rat: in vivo and in vitro studies. Am J Physiol 299:E39E46.

Pinilla L, Aguilar E, Dieguez C, Millar RP, Tena-Sempere M. 2012. Kisspeptins and reproduction: physiological roles and regulatory mechanisms. Physiol Rev 92:1235-1316.

Poling MC, Kim J, Dhamija S, Kauffman AS. 2012. Development, sex steroid regulation, and phenotypic characterization of RFamide-related peptide (Rfrp) gene expression and RFamide receptors in the mouse hypothalamus. Endocrinology 153:1827-1840.

Quennell JH, Rizwan MZ, Relf H-L, Anderson GM. 2010. Developmental and steroidogenic effects on the gene expression of RFamide related peptides and their receptor in the rat brain and pituitary gland. J Neuroendocrinol 22: 309-316.

Reiter RJ. 1993. The melatonin rhythm: both a clock and a calendar. Experientia 49:654-664.

Reuss S, Olcese J. 1995. Neuropeptide Y: distribution of immunoreactivity and quantitative analysis in diencephalic structures and cerebral cortex of dwarf hamsters under different photoperiods. Neuroendocrinology 61: 337-347.

Revel FG, Saboureau M, Masson-Pévet M, Pévet P, Mikkelsen JD, Simonneaux V. 2006a. Kisspeptin mediates the photoperiodic control of reproduction in hamsters. Curr Biol $16: 1730-1750$

Revel FG, Saboureau M, Pevet P, Mikkelsen JD, Simonneaux V. 2006b. Melatonin regulates type 2 deiodinase gene expression in the Syrian hamster. Endocrinology 147: 4680-4687.

Revel FG, Saboureau M, Pévet P, Simonneaux V, Mikkelsen JD. 2008. RFamide-related peptide gene is a melatonindriven photoperiodic gene. Endocrinology 149:902-912.

Roberts AC, Martensz ND, Hastings MH, Herbert J. 1985. Changes in photoperiod alter the daily rhythms of pineal melatonin content and hypothalamic beta-endorphin content and the luteinizing hormone response to naloxone in the male Syrian hamster. Endocrinology 117:141-148.

Rogers KV, Vician L, Steiner RA, Clifton DK. 1988. The effect of hypophysectomy and growth hormone administration on pre-prosomatostatin messenger ribonucleic acid in the periventricular nucleus of the rat hypothalamus. Endocrinology 122:586-591.

Schneider JE. 2004. Energy balance and reproduction. Physiol Behav 81:289-317.
Schulz C, Paulus K, Lobmann R, Dallman M, Lehnert H. 2010. Endogenous ACTH, not only alpha-melanocyte-stimulating hormone, reduces food intake mediated by hypothalamic mechanisms. Am J Physiol 298:E237-E244.

Simonneaux V, Ancel C. 2012. RFRP neurons are critical gatekeepers for the photoperiodic control of reproduction. Front Endocrinol 3:1-9.

Skinner DC, Herbison E. 1997. Effects of photoperiod on estrogen receptor, tyrosine hydroxylase, neuropeptide $Y$, and beta-endorphin immunoreactivity in the ewe hypothalamus. Endocrinology 138:2585-2595.

Smith JT, Cunningham MJ, Rissman EF, Clifton DK, Steiner RA. 2005. Regulation of Kiss 1 gene expression in the brain of the female mouse. Endocrinology 146:3686-3692.

Smith JT, Coolen LM, Kriegsfeld LJ, Sari IP, Jaafarzadehshirazi MR, Maltby M, Bateman K, Goodman RL, Tilbrook AJ, Ubuka T, Bentley GE, Clarke IJ, Lehman MN. 2008. Variation in kisspeptin and RFamide-related peptide (RFRP) expression and terminal connections to gonadotropinreleasing hormone neurons in the brain: a novel medium for seasonal breeding in the sheep. Endocrinology 149: 5770-5782.

Stengel A, Goebel M, Wang L, Rivier J, Kobelt P, Monnikes H, Tache Y. 2010. Selective central activation of somatostatin receptor 2 increases food intake, grooming behavior and rectal temperature in rats. J Physiol Pharmacol 61: 399-407.

Stengel A, Karasawa H, Taché Y. 2015. The role of brain somatostatin receptor 2 in the regulation of feeding and drinking behavior. Horm Behav 73:15-22.

Thompson EL, Patterson M, Murphy KG, Smith KL, Dhillo WS, Todd JF, Ghatei MA, Bloom SR. 2004. Central and peripheral administration of kisspeptin-10 stimulates the hypothalamic-pituitary-gonadal axis. J Neuroendocrinol 16:850-858.

Ubuka T, Inoue K, Fukuda Y, Mizuno T, Ukena K, Kriegsfeld LJ, Tsutsui K. 2012. Identification, expression, and physiological functions of Siberian hamster gonadotropininhibitory hormone. Endocrinology 153:373-385.

Vale W, Brazeau P, Grant G, Nussey A, Burgus R, Rivier J, Ling N, Guillemin R. 1972. Preliminary observations on the mechanism of action of somatostatin, a hypothalamic factor inhibiting the secretion of growth hormone. C R Hebdomadaires Acad Sci 275:2913-2916.

Webb SM, Champney TH, Vaughan MK, Reiter RJ. 1985. Effect of long and short photoperiod and/or pinealectomy on immunoreactive somatostatin in the Syrian hamster. Horm Metab Res 17:107-108.

Zar JH. 1999. Biostatistical analysis, $4^{\text {th }}$ ed. Englewood Cliffs, $\mathrm{NJ}$ : Prentice Hall. 